\title{
Analisis Harga Saham PT Astra Internasional Tbk Menggunakan Data Dari Bursa Efek Indonesia dalam Jangka Waktu Pendek Menggunakan Metode Naïve Bayes dan Decision Tree-J48
}

\author{
Heima Sitorus dan Yusran Tarihoran \\ Fakultas Teknologi Informasi, Universitas Advent Indonesia
}

\begin{abstract}
Abstrak
Prediksi harga saham merupakan tindakan yang sangat diperlukan sebagai langkah awal untuk mengambil keputusan untuk menentukan kapan akan melakukan transaksi penjualan dan pembelian sebuah saham yang ada di bursa efek Indonesia. Prediksi harga saham dilakukan dengan menggunakan dua metode yang akan dibandingkan, yaitu; Metode Naïve Bayes dan Metode Decision Tree-J48. Jumlah data yang digunakan adalah sebanyak 1.195 dan data yang digunakan sebagai data testing adalah sebanyak $20 \%$ atau 239 data. Adapun hasil dari tingkat akurasi dari Metode Naïve Bayes menggunakan data testing adalah 92.0502 \%. Dengan presentasi untuk nilai precision atau tingkat ketepatan informasi yang diharapkan oleh penulis dengan jawaban yang diberikan oleh sistem sebesar 0.920 dan nilai untuk recall atau tingkat keberhasilan tehadap informasi yang ditemukan kembali oleh sistem sebesar 0,961.

Sedangkan hasil prediksi dengan menggunakan metode Decision Tree J-48 untuk hasil akurasi dengan menggunakan data testing adalah sebesar $98.7448 \%$. \%. Dengan presentasi untuk nilai precision atau tingkat ketepatan informasi yang diharapkan oleh penulis dengan jawaban yang diberikan oleh sistem. sebesar 0.989 dan nilai untuk recall atau tingkat keberhasilan tehadap informasi yang ditemukan kembali oleh sistem sebesar 0.997
\end{abstract}

Kata Kunci: Harga saham, Bursa Efek Indonesia, Naïve Bayes, Decision tree-J48, WEKA.

\section{Analysis of PT Astra International Tbk's Share Price Using Data from the Indonesia Stock Exchange in Short Term Period Using the Naïve Bayes Method and Decision Tree-J48}

\begin{abstract}
Stock price prediction is a very necessary action as a first step to taking the decision to determine when to transact a sale and purchase of existing shares in Indonesia stock exchange. Stock price prediction is done using two methods are compared, i.e.; Naive Bayes method and the method of Decision Tree-J48. The amount of data used is as much as 1,195 and data used as the data for testing is as much as $20 \%$ or 239 the data.

As a result of the level of accuracy of the Naive Bayes Method using data testing is $92.0502 \%$. With the presentation for the value of precision or accuracy of information expected by the author with the answers given by the system of 0920 and the value for the recall or the success rate of taking action against information found by the system of 0.961.

While the results of a prediction using Decision Tree $J-48$ results for accuracy using data testing is $98.7448 \%$. \%. With the presentation for the value of precision or accuracy of information expected by the author with the answers given by the system. of 0.989 and value for the recall or the success rate of taking action against information found by the system of 0.997.

Keywords: Stock price, Indonesia stock exchange, Naïve Bayes, Decision tree-J48, WEKA.

\section{Pendahuluan}

Pasar modal dapat mempermudah masyarakat dan para investor untuk mengetahui perkembangan tentang harga saham setiap perusahaan-perusahaan di Indonesia yang sudah go public. Salah satu perusahaan yang sudah terdaftar di bursa efek Indonesia dan telah go public adalah PT Astra Internasional Tbk. Masyarakat yang ingin mengetahui harga saham PT Astra Internasional Tbk setiap harinya dapat melihatnya di bursa efek Indonesia.
\end{abstract}


Keterbukaan data harga saham yang dimiliki oleh PT Astra Internasional Tbk, hal ini dapat digunakan oleh masyarakat dan para investor untuk mendapatkan keuntungan. Namun, untuk mendapatkan keuntungan, maka masyarakat dan para investor harus mengetahui waktu yang tepat untuk melakukan penjualan dan pembelian saham yang diinginkan di PT Astra Internasional Tbk.

\section{Landasan Teori Harga Saham}

Harga saham adalah harga penutup yang sering ditampilkan di bursa efek Indonesia atau di pasar modal Indonesia yang menampilkan grafik atau harga yang dapat digunakan masyarakat, investor dan perusahaan-perusahaan yang ingin melakukan penjualan dan pembelian saham, sehingga memberikan keuntungan secara pribadi.

Menurut Supranto. J menyatakan bahwa "Indeks harga saham adalah angka indeks harga saham yang telah disusun dan dihitung sedemikian rupa sehingga menghasilkan tren. Angka indeks merupakan angka yang dibuat sedemikian rupa sehingga dapat dipergunakan untuk membandingkan kegiatan ekonomi atau peristiwa, bisa berupa perubahaan harga saham dari waktu ke waktu".

Untuk dapat melakukan analisis harga saham, ada dua teknik analisis yang sering digunakan, yaitu:

1. Analisis Fundamental

Analisis fundamental adalah metode analisis yang didasari pada ekonomi suatu perusahaan. Analisis ini juga sering digunakan untuk melakukan analisis perusahaan dalam bidang keuangan. Analisis ini juga sering digunakan oleh pihak-pihak yang ingin mengetahui tentang harga saham dalam jangka waktu yang lama atau dalam jangka waktu yang panjang.[2]

2. Analisis Teknikal

Analisis teknikal adalah analisis yang sering menggunakan data-data yang sudah lampau, terutama pergerakan harga dan volume. Analisis teknikal merupakan suatu metodologi untuk memprediksi harga saham berdasarkan kondisi penawaran dan permintaan terhadap saham tersebut.[2] Untuk dapat menganalisis harga saham, maka hal yang akan diperhatikan penulis adalah sebagai berikut:

- Prev atau previous adalah harga penutupan saham pada hari bursa sebelumnya. Misalnya jika hari ini adalah hari Selasa, maka prev menunjukkan harga penutupan pada hari sebelumnya, yaitu hari Senin.

- Harga tertinggi adalah harga tertinggi saham yang terjadi hari itu juga

- Harga terendah adalah harga yang paling rendah yang terjadi hari itu.

- Frekuensi perdagangan saham adalah berapa kali transaksi jual beli terjadi pada saham yang bersangkutan pada waktu tertentu.

- Individual indek merupakan jumlah indeks saham yang ada di dalam pasar modal.

- Volume ini menentukan jumlah transaksi yang diperdagangkan dalam pasar pada satu periode tertentu.

- Value merupakan jumlah saham yang terjual dalam satu waktu.

\section{Metode Penelitian \\ Data Mining}

Data Mining (DM) adalah salah satu bidang yang saat ini mengalami perkembangan yang sangat pesat karena besarnya kebutuhan terhadap nilai tambah dari database berskala besar, yang makin banyak terakumulasi sejalan dengan pertumbuhan teknologi informasi. Definisi umum dari Data mining itu sendiri merupakan proses yang dilakukan untuk menggali nilai tambah berupa pengetahuan dari sekumpulan data yang selama ini tidak dianggap penting oleh masyarakatnya.

Data mining, sering juga disebut sebagai Knowledge Discovery in Database (KDD). KDD adalah kegiatan yang meliputi pengumpulan, pemakaian data, historis untuk menemukan keteraturan, pola atau hubungan dalam set data berukuran besar.

Menurut Achmad Basuki Proses dalam tahapan data mining terdiri dari tiga langkah utama, yaitu:

1. Data Preparation. Pada langkah ini data dipilih dibersihkan dan dilakukan preprocessed.

2. Penggunaan Algoritma data mining.

3. Tahap Analisa Keluaran dari data mining dievaluasi untuk melihat apakah knowledge domain ditemukan dalam bentuk rule yang telah diekstrak. 


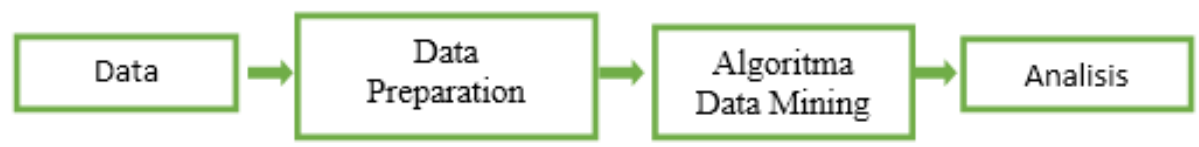

Gambar 1 Langkah-langkah dalam Proses Data Mining

\section{Algoritma Naive Bayes}

Algoritma Naive Bayes merupakan salah satu algoritma yang terdapat pada teknik klasifikasi. Naive Bayesmerupakan pengklasifikasian dengan metode probabilitas dan statistik yang dikemukan oleh ilmuwan Inggris. Thomas Bayes, yaitu memprediksi peluang di masa depan berdasarkan pengalaman dimasa sebelumnya sehingga dikenal sebagai Teorema Bayes. Teorema tersebut dikombinasikan dengan Naive dimana diasumsikan kondisi antar atribut saling bebas. Klasifikasi Naive Bayes diasumsikan bahwa ada atau tidak ciri tertentu dari sebuah kelas tidak ada hubungannya dengan ciri dari kelas lainnya. Persamaan dari teorema Bayes adalah:

$$
\begin{aligned}
\mathrm{P}(\mathrm{s} \mid \mathrm{x}) & =\frac{\operatorname{argmax}}{x \in X} \frac{P(y \mid x) P(x)}{P(X)} \\
& =\frac{\operatorname{argmax}}{x \in X} P((y \mid x) P(X)
\end{aligned}
$$

\section{Metode Decision Tree J-48}

Metode Decision Tree J-48 merupakan salah satu kelas yang terdapat pada program data mining yang ada di software weka. Algoritma 348 merupakan implementasi dari program algoritma C4.5

Maka secara umum Algoritma J-48 biasanya digunakan untuk masalah klasifikasi. Sebuah decision tree terdiri dari beberapa simpul yaitu tree's root, internal node dan leafs. Konsep entropi digunakan untuk penentuan pada atribut mana sebuah pohon terbagi (split). Semakin tinggi entropy sebuah sampel, semakin tidak murni sampel tersebut.

Rumus yang digunakan untuk menghitung "entropy"sampel S adalah;

$$
\begin{aligned}
& \operatorname{Entropy}(S)=\sum \tau-p i \log 2 p i \\
& \text { Atau } \\
& \operatorname{Entropy}(S)=-p 1 \log 2 p 1-p 2 \log 2 p 2
\end{aligned}
$$

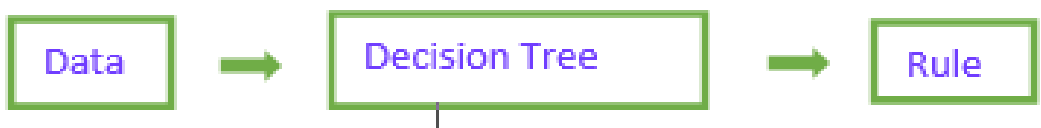

\section{Waikato Environment Knowledge And Analisys (WEKA)}

WEKA adalah sebuah perangkat lunak data mining/machine learning yang dibangun oleh Department of Computer Science University of Waikato di New Zealand. WEKA mampu untuk menyelesaikan masalah-masalah yang berhubungan dengan data mining yang ada didunia nyata, khususnya klasifikasi yang mendasari pendekatan terhadap machine learning.

Secara umum WEKA menyediakan 3 fasilitas untuk data mining. Ketiga fasilitas tersebut adalah data processing, data mining dan visualization tools. 


\section{Analisa dan Metode Penelitian}

Pengumpulan data dan Pengolahan Data Saham BEI. Data penelitian yagn digunakan oleh penulis adalah data yang telah di publikasikan melalui website Bursa Efek Indonesia (http://www.idx.co.id/idid/beranda/unduhdata/ringkasan.aspx.)

\section{Data Saham}

Pengumpulan data PT Astra Internasional Tbk yang dilakukan secara manual. Data yang diambil penulis adalah data harian yang mulai dari tanggal 1 Januari 2013 sampai dengan 30 November 2017. Namun data yang telah didapatkan dari website resmi bursa efek Indonesia masih harus dikelolah ulang, karena data yang dihasilkan dari website tersebut masih merupakan gabungan dari data harga saham perusahaan-perusahaan yang telah terdaftar.

\begin{tabular}{|c|c|c|c|c|c|c|c|c|c|}
\hline \multicolumn{10}{|c|}{ Daily Trading PT ASTRA INTERNASIONAL Tbk 2013 - 2017} \\
\hline NO & Date & Previous & High & Low & Close & Volume & Value & Frequency & Output \\
\hline 1 & 2-Jan-13 & 7600 & 7700 & 7450 & 7500 & 23374000 & $1.77427 \mathrm{E}+11$ & 1753 & Naik \\
\hline 2 & 3-Jan-13 & 7500 & 7900 & 7500 & 7850 & 70205000 & $5.42508 \mathrm{E}+11$ & 4567 & Turun \\
\hline 3 & 4-Jan-13 & 7850 & 7850 & 7750 & 7850 & 29485000 & $2.30094 \mathrm{E}+11$ & 2989 & Turun \\
\hline 4 & 7-Jan- -13 & 7850 & 7850 & 7700 & 7750 & 20890000 & $1.62279 \mathrm{E}+11$ & 1863 & Turun \\
\hline 5 & 8-Jan-13 & 7750 & 7800 & 7600 & 7650 & 24269500 & $1.86656 \mathrm{E}+11$ & 1969 & Turun \\
\hline 6 & 9-Jan-13 & 7650 & 7750 & 7650 & 7700 & 38907000 & $2.99253 \mathrm{E}+11$ & 1936 & Naik \\
\hline 7 & 10--Jan-13 & 7700 & 7700 & 7300 & 7350 & 50290500 & $3.74987 \mathrm{E}+11$ & 5175 & Turun \\
\hline 8 & 11-Jan-13 & 7350 & 7500 & 7300 & 7300 & 33422500 & $2.46395 \mathrm{E}+11$ & 3791 & Naik \\
\hline 9 & 12-Jan-13 & 7300 & 7500 & 7350 & 7500 & 28014000 & $2.08141 \mathrm{E}+11$ & 2429 & Turun \\
\hline 10 & 13-Jan-13 & 7500 & 7600 & 7500 & 7600 & 32451000 & $2.44975 \mathrm{E}+11$ & 2845 & Naik \\
\hline 11 & 16-Jan-13 & 7600 & 7650 & 7500 & 7650 & 23595000 & $1.79349 \mathrm{E}+11$ & 2810 & Turun \\
\hline 12 & 17-Jan-13 & 7650 & 7650 & 7500 & 7500 & 27764000 & $2.1031 \mathrm{E}+11$ & 2403 & Turun \\
\hline 13 & 18-Jan-13 & 7500 & 7750 & 7550 & 7750 & 34305000 & $2.63287 \mathrm{E}+11$ & 2963 & Naik \\
\hline
\end{tabular}

Gambar 3 Contoh Daftar harga saham PT Astra Internasional Tbk 2013-2017

\section{Block Diagram Penelitian}

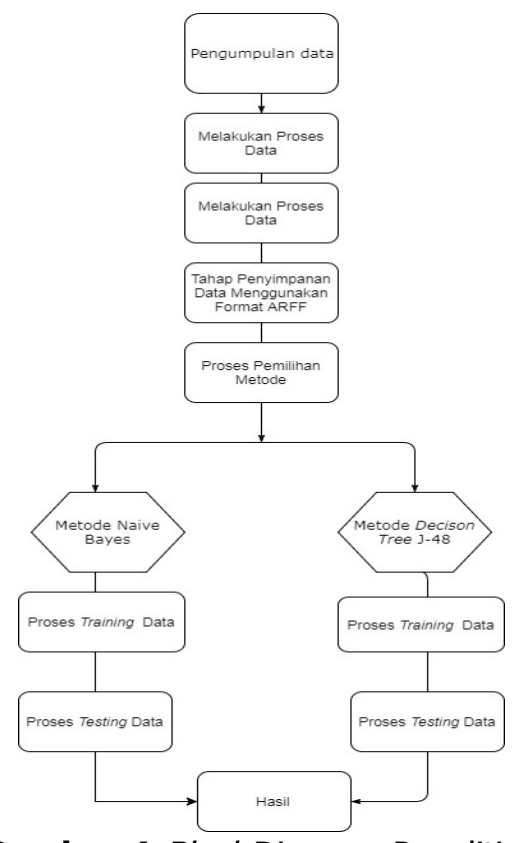

Gambar 4 Block Diagram Penelitian 


\section{Keterangan Block Diagram:}

1. Pengumpulan data merupakan proses pengambilan data yang terdapat dari website PT Astra Internasional Tbk dengan periode 1 Januari 2013 sampai dengan periode 30 November 2017.

2. Melakukan proses data yang pertama adalah memisahakan data PT Astra Internasional Tbk kedalam satu file dan disimpan di Microsoft Excel 2013.

3. Proses data yang kedua adalah menyimpan data dengan format.Cvs.

4. Setelah data disimpan dengan format.Cvs, bukalah software WEKA, dan bukalah file, dan simpan dengan format.Arff.

5. Lalu, pilih tool Classify, dan pilihlah metode yang diinginkan. Dalam penelitian ini penulis menggunkaan metode Naïve Bayes dan Decision Tree J-48.

6. Setelah memilih metode yang digunakan, maka langkah selanjutnya yang dilakukan adalah membuka file yang telah disimpan dengan format.Arff, maka pilihlah use training set untuk mendapatkan hasil data training dengan menggunakan metode Naïve Bayes dan Decision Tree J48.

7. Hasil data training yang sudah didapat, maka harus dijadikan menjadi data acuan untuk mendapatkan hasil data testing. Untuk mendapatkan hasil data testing, pilihlah data yang dijadikan diuji sebagai data testing, lalu pilihlah tool supplied test set, dan pilih data yang diuji oleh WEKA.

8. Setelah melakukan proses training dan proses testing maka akan mendapatkan hasil data training data testing dengan menggunakan metode Naïve Bayes dan Decision Tree J-48.

\section{Hasil Pengujian Dan Penelitian \\ Pengujian Data}

Pengujian data dilakukan dengan menggunakan bantuan software yang dapat sekaligus digunakan untuk pengolah data, yaitu adalah WEKA. Data harga saham yang telah dikumpulkan dan disimpan di program Excel, lalu disimpan dengan format CVS (Concurrent Versioning System).

Selanjutnya data yang telah disimpan dapat dibuka di program weka, selanjutnya disimpan ulang dengan format ARFF (Andrew's Ridiculos File Format).

\section{Pengujian Data Training}

Jumlah data yang akan di training yaitu sebanyak 1195 yang Merupakan Data yang sudah disiapkan dan yang sudah berbentuk Arff.

Tabel 1 Hasil Naïve Bayes dan Decision Tree J-48 di WEKA

\begin{tabular}{|l|l|l|}
\hline $\begin{array}{l}\text { Jumlah Harga } \\
\text { Saham }\end{array}$ & $\begin{array}{l}\text { Naïve } \\
\text { Bayes }\end{array}$ & $\begin{array}{l}\text { Decision } \\
\text { Tree J-48 }\end{array}$ \\
\hline Benar & 1010 & 1182 \\
\hline Salah & 185 & 13 \\
\hline
\end{tabular}

Keterangan Tabel 1 yaitu:

1. Naïve Bayes

Terdapat 1010 data harga saham yang ditentukan oleh WEKA yang diklasifikasikan benar. Dan sebanyak 185 data harga saham yang dinyatakan oleh WEKA yang diklasifikasikan mengalami kesalahan.

2. Decision Tree $\mathrm{J}-48$

Terdapat 1182 data harga saham yang ditentukan oleh WEKA yang diklasifikasikan benar. Dan sebanyak 13 data harga saham yang dinyatakan oleh WEKA yang diklasifikasikan mengalami kesalahan. 


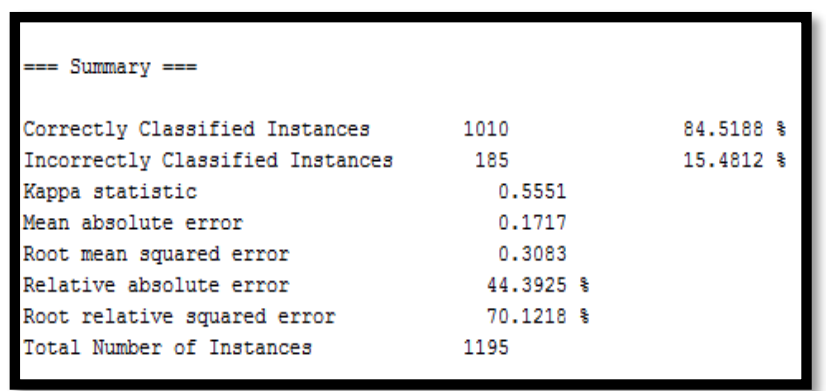

Gambar 5 Summary dengan menggunakan metode Naïve Bayes

Keterangan berdasarkan Gambar 5 adalah sabagai berikut:

1. Correctly Classified Instance

Rumus untuk mencari nilai akurasi adalah:

$$
\begin{gathered}
\text { Akurasi }=\frac{\text { jumlah prediksi harga saham yang benar }}{\text { Total jumlah data prediksi }} \\
\text { Akurasi }=\frac{\mathrm{f}_{0}+\mathrm{f}_{3}}{\mathrm{f}_{0}+\mathrm{f}_{1}+\mathrm{f}_{2}+\mathrm{f}_{3}} \\
\text { Akurasi }=\frac{838+172}{838+141+44+172} \\
\text { Akurasi }=\frac{1010}{1195}=0.845188 \\
\text { Presentasi Akurasi }=0.8451 * 100=84.5188 \%
\end{gathered}
$$

\section{Incorrectly Classified Instance}

$$
\begin{gathered}
\text { Error Rate }=\frac{\text { jumlah prediksi harga saham yang salah }}{\text { Total jumlah data prediksi }}= \\
\text { Error Rate }=\frac{f_{1}+f_{2}}{f_{0}+f_{1}+f_{2}+f_{3}} \\
\text { Error Rate }=\frac{141+44}{838+141+44+172}= \\
\text { Akurasi }=\frac{185}{1195}=0.154812 \\
\text { Presentasi Akurasi }=0.154811 * 100=15.4812 \%
\end{gathered}
$$

3. Total Number Of Instance

Total Number of Instance merupakan jumlah data yang digunakan dalam proses training yaitu sebanyak 1.195. 


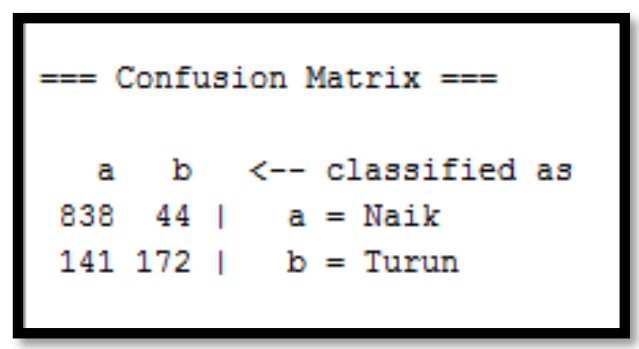

Gambar 6 Confusion Matrix

Keterangan dari Gambar 6 adalah sebagai berikut:

Pada baris pertama menerangkan bahwa terdapat sebanyak 838 data harga saham dari classified "Naik" yang diklasifikasikan mengalami penaikan harga, dan terdapat 44 data harga saham yang seharusnya mengalami penaikan harga saham, namu salah diklasifikasikan menjadi mengalami penurunan harga saham.

Pada baris kedua menerangkan bahwa terdapat 172 data harga saham dari classified "Turun" yang diklasifikasikan mengalami penurunan harga saham, namun terdapat 141 data harga saham yang seharusnya mengalami penurunan harga saham, namun yang salah diklasifikasikan menjadi mengalami penaikan harga saham.

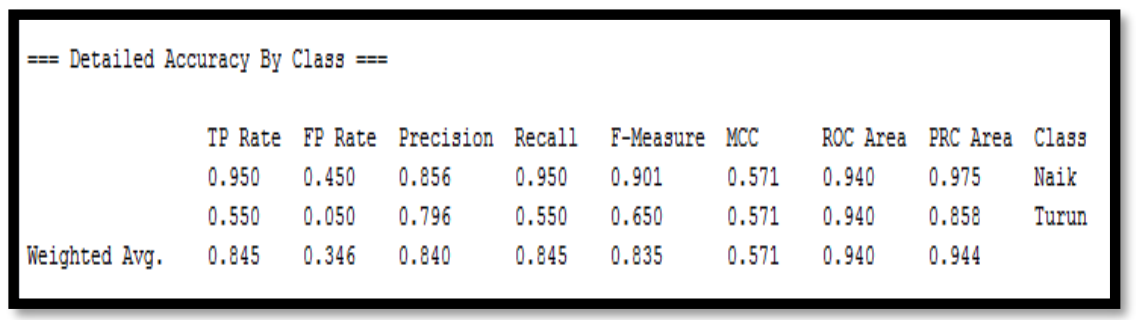

Gambar 7 Detailed Accuracy

Keterangan Gambar 7 adalah:

1. True positif Rate (TP Rate)

TP Rate atau True positif Rate adalah jumlah tingkat kebenaran dari data harga saham yang diklasifikasikan sebagai kelas $\mathrm{x}$, diantara semua data harga saham yang benar memiliki kelas $\mathrm{x}$ yang bernilai sama dengan recall.

Untuk memcari nilai TP Rate pada kelas harga saham yang Naik adalah:

$$
\begin{array}{r}
\text { True Positif Rate }=\frac{\text { Jumlah data yang benar }}{\text { Jumlah data yang benar }+ \text { Jumlah data yang salah }} \\
\text { True Positif Rate }=\frac{838}{838+44}=0,950
\end{array}
$$

Untuk memcari nilai FN atau False Negative pada kelas harga saham yang Turun adalah:

2. False Positive (FP Rate)

$$
\begin{gathered}
\text { False Negative }=\frac{\text { Jumlah data yang salah }}{\text { Jumlah data yang banar }+ \text { Jumlah data yang salah }} \\
\text { True Positif Rate }=\frac{172}{172+141}=0,550
\end{gathered}
$$

Untuk mencari nilai False Positive adalah nilai harga saham yang diklasifikasikan sebagai kelas $\mathrm{x}$, tetapi masuk kedalam kelas yang berbeda, dan yang bukan dari kelas $\mathrm{x}$ itu sendiri: 
Untuk mencari nilai False Positive pada kelas yang memiliki data harga saham naik:

$$
\begin{gathered}
\text { False Positive }=\frac{\text { Jumlah data yang benar }}{\text { Jumlah data yang benar }+ \text { Jumlah data yang salah }} \\
\text { False Positive }=\frac{141}{141+172}=0,450
\end{gathered}
$$

Untuk mencari False Negative pada kelas yang turun adalah:

$$
\begin{aligned}
& \text { FalseNegative }=\frac{\text { Jumlah data }}{\text { Jumlah data yang benar } * \text { Jumlah data yang salah }} \\
& \text { False Negative }=\frac{838+44+141+172}{141 * 172}=0,050
\end{aligned}
$$

\section{Precision}

Precision merupakan tingkat ketepatan informasi yang diharapkan oleh penulis dengan jawaban yang diberikan oleh sistem.

Untuk mencari nilai Precision dari kelas Naik:

Untuk mencari nilai Precision dari kelas Turun:

$$
\begin{aligned}
\text { Precision }= & \frac{\text { Jumlah data benar }}{\text { Jumlah data yang benar }+ \text { Jumlah data yang salah }} \\
& \text { False Negative }=\frac{838}{838+141}=0,856
\end{aligned}
$$

$$
\begin{aligned}
\text { Precision }= & \frac{\text { Jumlah data salah }}{\text { Jumlah data yang benar }+ \text { Jumlah data yang salah }} \\
& \text { False Negative }=\frac{172}{172+44}=0,796
\end{aligned}
$$

4. Recall

Recal/merupakan tingkat keberhasilan sistem dalam menemukan kembali informasi.

Cara mencari nilai Recal/ dalam kelas "Naik"

$$
\begin{gathered}
\text { Recall }=\frac{\text { Jumlah data yang benar }}{\text { Jumlah data yang benar }+ \text { Jumlah data yang salah }} \\
\text { Recall }=\frac{838}{838+44}=0,950
\end{gathered}
$$

Untuk memcari nilai Cara mencari nilai Recal/ dalam kelas "Turun"

$$
\begin{gathered}
\text { Recall }=\frac{\text { Jumlah data yang salah }}{\text { Jumlah data yang banar }+ \text { Jumlah data yang salah }} \\
\text { Recall }=\frac{172}{172+141}=0,550
\end{gathered}
$$

5. F-Measure

F-Measure merupakan gabungan penhitungan dari nilai Precision dan Recall.

Untuk mencari nilai F-Measure adalah:

$$
F-\text { Measure }=\frac{2 * \text { Precision } * \text { Recall }}{\text { Precision } * \text { Recall }}
$$

nilai F-Measure untuk data harga saham naik adalah: 
nilai F-Measure untuk data harga saham turun adalah:

$$
F-\text { Measure }=\frac{2 * 0.856 * 0.950}{0.856+0.950}=0.901
$$

$$
F-\text { Measure }=\frac{2 * 0,796 * 0.550}{0,796+0.550}=0.650
$$

\section{Pengujian data testing}

Data testing merupakan $20 \%$ dari jumlah data yang telah dikumpulkan. Jumlah data yang digunakan adalah sebanyak 1195, maka data yang digunakan sebagai data testing adalah sebanyak 239 yang diambil secara acak. Untuk melakukan pengujian kepada data testing yang belum diketahui kebenarannya, maka diperlukan beberapa proses sebagai berikut:

1. Siapkan data yang di testing, dan simpan dengan format file .arff,

2. Siapkan hasil data training yang akan dijadikan sebagai acuan dalam menentukan klasifikasi data testing,

3. Lakukan pengujian dengan menggunakan program WEKA.

\section{Pengujian Dengan Metode Naïve Bayes}

Berikut adalah hasil dari pengujian data testing dengan program WEKA

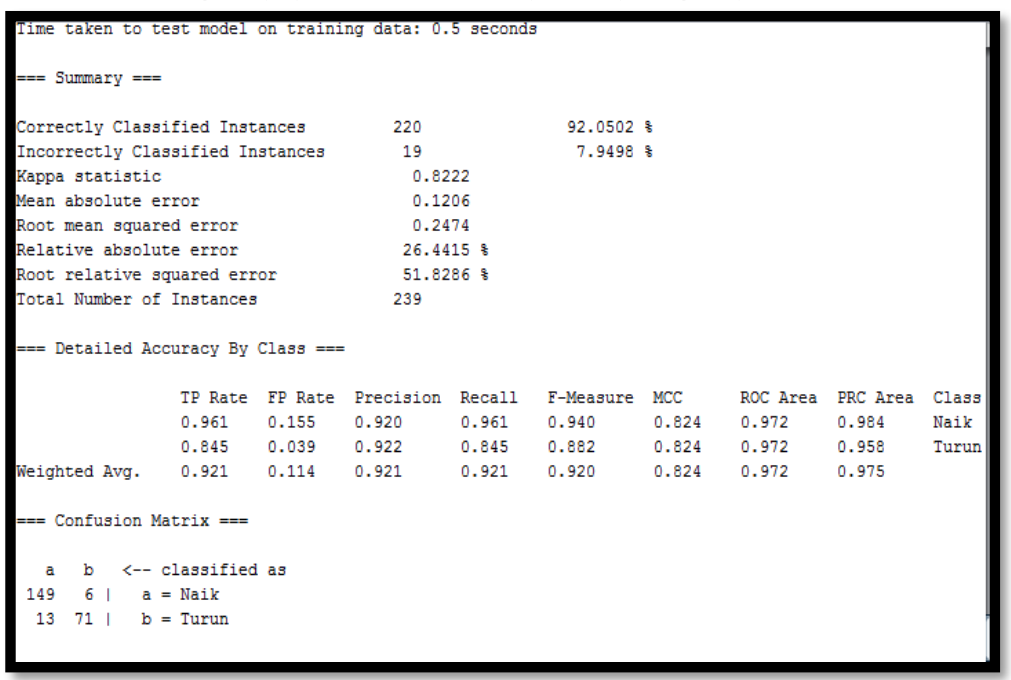

Gambar 8 Hasil Prediksi WEKA Naïve Bayes

Tabel 2 Klasifikasi Data Testing Naïve Bayes

\begin{tabular}{|l|l|l|}
\hline $\begin{array}{l}\text { Prediction } \\
\text { output }\end{array}$ & Frekuensi & $\begin{array}{l}\text { Total Jumlah } \\
\text { Data }\end{array}$ \\
\hline Benar & 220 & 239 \\
\hline Salah & 19 & 239 \\
\hline
\end{tabular}




\begin{tabular}{crrl}
\hline$==$ Predictions & on test set $===$ & \\
inst\# & actual & predicted error prediction \\
1 & $1: ?$ & $1:$ Naik & 0.98 \\
2 & $1: ?$ & $2:$ Turun & 1 \\
3 & $1: ?$ & $1:$ Naik & 0.989 \\
4 & $1: ?$ & $1:$ Naik & 0.981 \\
5 & $1: ?$ & $1:$ Naik & 0.985 \\
6 & $1: ?$ & $1:$ Naik & 0.942 \\
7 & $1: ?$ & $2:$ Turun & 0.812 \\
8 & $1: ?$ & $2:$ Turun & 1 \\
9 & $1: ?$ & $1:$ Naik & 0.733 \\
10 & $1: ?$ & $1:$ Naik & 0.543 \\
11 & $1: ?$ & $1:$ Naik & 0.975 \\
12 & $1: ?$ & $1:$ Naik & 0.977 \\
13 & $1: ?$ & $1:$ Naik & 0.984 \\
14 & $1: ?$ & $1:$ Naik & 0.636 \\
15 & $1: ?$ & $1:$ Naik & 0.634 \\
16 & $1: ?$ & $1:$ Naik & 0.906
\end{tabular}

Gambar 9 Contoh Hasil prediksi harga saham data Testing Naïve Bayes

Keterangan Gambar Gambar 9 adalah:

1. Inst\# merupakan penomoran untuk setiap data yang ditest, Actual adalah output yang belum di isi hasilnya, dan hanya diisi dengan tanda tanya (?), Predicted merupakan klasifikasi output yang dihasilkan oleh program WEKA itu sendiri,

2. Error prediction merupakan presentasi jumlah kesalahan yang terjadi.

\section{Pengujian Dengan Metode Decision Tree J-48}

Berikut adalah hasil dari pengujian data training dengan program WEKA.

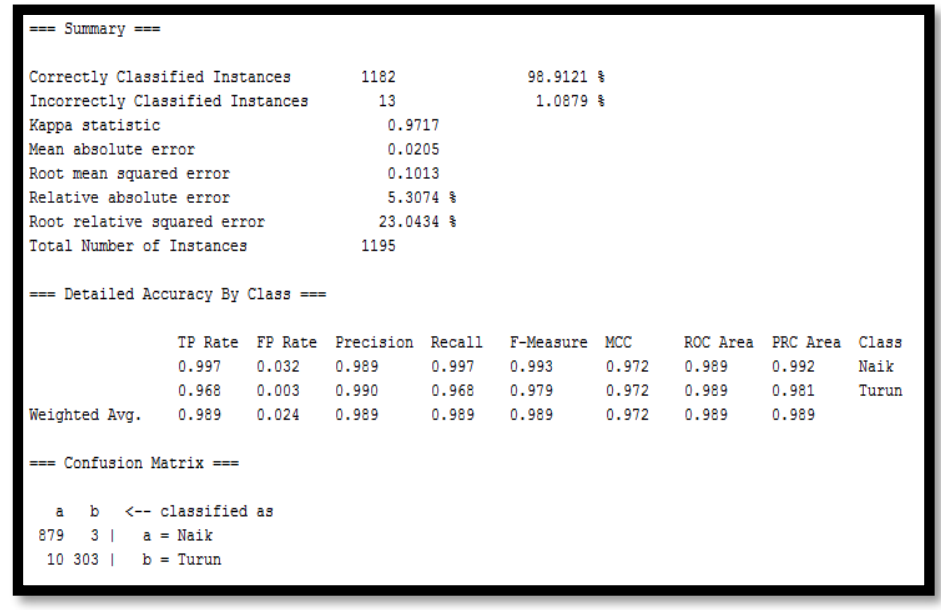

Gambar 10 Pengujian data training J-48

Berikut adalah hasil dari pengujian data testing dengan program WEKA 


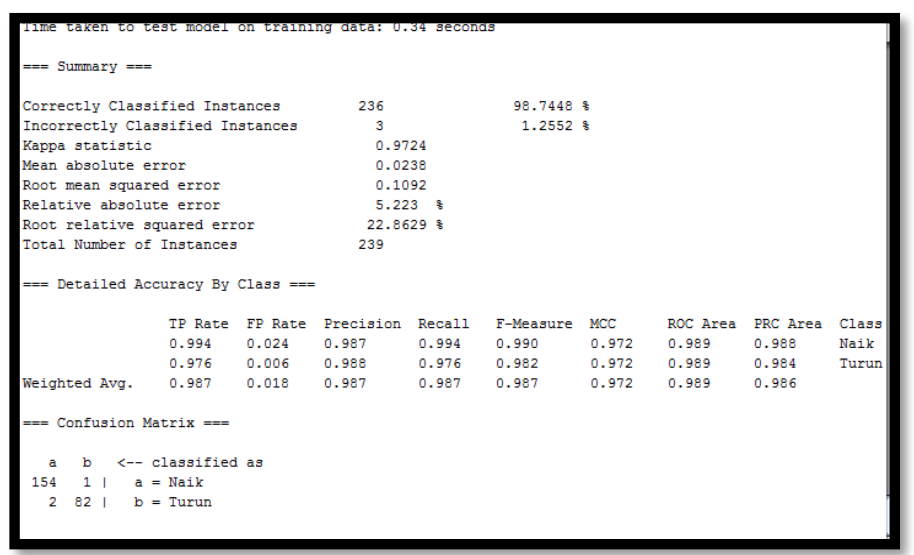

Gambar 11 Hasil Klasifikasi dengan Metode Decision Tree J-48

Tabel 3 Klasifikasi Data Testing

\begin{tabular}{|l|l|l|}
\hline $\begin{array}{l}\text { Prediction } \\
\text { output }\end{array}$ & Frekuensi & $\begin{array}{l}\text { Total Jumlah } \\
\text { Data }\end{array}$ \\
\hline Benar & 236 & 239 \\
\hline Salah & 3 & 239 \\
\hline
\end{tabular}

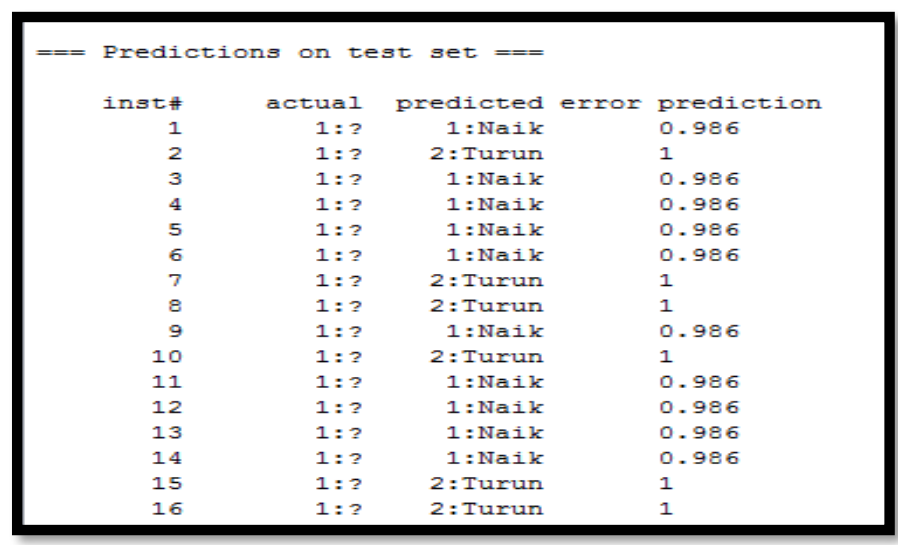

Gambar 12 Contoh Hasil Prediksi Decision Tree J-48

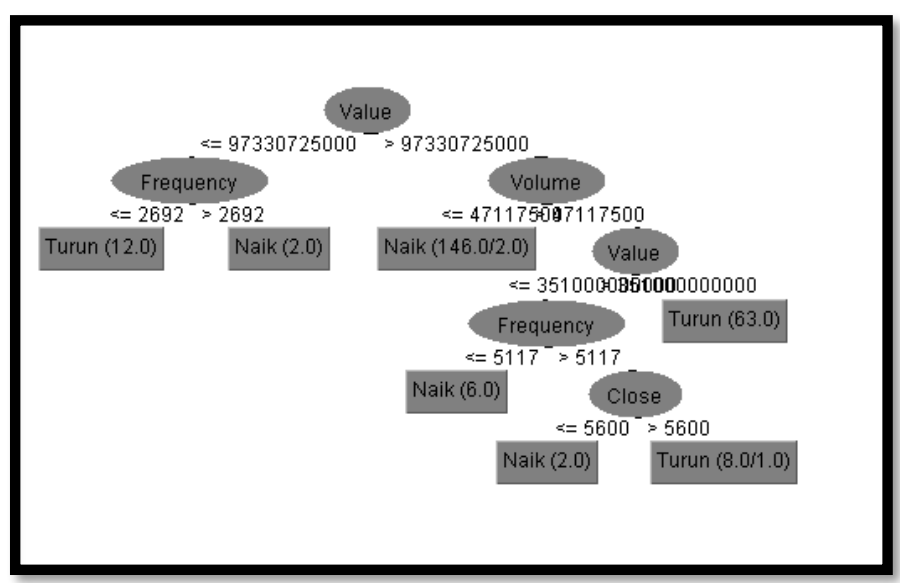

Gambar 13 Hasil Klasifikasi Decision Tree J-48 


\section{Hasil Penelitian}

Tabel 4 Hasil Akurasi dan Error Rate pada Naïve Bayes

\begin{tabular}{|l|l|l|}
\hline $\begin{array}{l}\text { Output } \\
\text { Prediction }\end{array}$ & Akurasi & Error Rate \\
\hline $\begin{array}{l}\text { Data } \\
\text { Training }\end{array}$ & $84.52 \%$ & $15.48 \%$ \\
\hline $\begin{array}{l}\text { Data } \\
\text { Testing }\end{array}$ & $92.05 \%$ & $7.95 \%$ \\
\hline
\end{tabular}

Tabel 5 Hasil Akurasi dan Error Rate pada Decision Tree J-48

\begin{tabular}{|l|l|l|}
\hline $\begin{array}{l}\text { Output } \\
\text { Prediction }\end{array}$ & Akurasi & $\begin{array}{l}\text { Error } \\
\text { Rate }\end{array}$ \\
\hline $\begin{array}{l}\text { Data } \\
\text { Training }\end{array}$ & $98.91 \%$ & $1.09 \%$ \\
\hline $\begin{array}{l}\text { Data } \\
\text { Testing }\end{array}$ & $98.74 \%$ & $1.26 \%$ \\
\hline
\end{tabular}

\section{Kesimpulan dan Saran Kesimpulan}

Berdasarkan penelitian yang dilakukan penulis terhadap harga saham PT Astra Internasional Tbk, maka didapatkan kesimpulan bahwa:

1. Dengan menggunakan metode Naïve Bayes didapat hasil presentasi akurasi untuk data training sebesar $84.5188 \%$ dan untuk hasil data testing sebesar $92.0502 \%$.

2. Dengan keterangan 149 data harga saham yang diklasifikasikan mengalami penaikan harga, dan terdapat 6 data harga saham yang seharusnya mengalami penaikan harga saham, namun diklasifikasikan mengalami penurunan harga saham. Dan terdapat 71 data harga saham yang diklasifikasikan benar mengalami penurunan harga saham, namun terdapat 13 data harga saham yang seharusnya mengalami penurunan harga saham, tetapi diklasifikasikan mengalami penaikan harga saham.

3. Dengan presentasi untuk nilai precision atau tingkat ketepatan informasi yang diharapkan oleh penulis dengan jawaban yang diberikan oleh sistem sebesar 0.920 dan nilai untuk recall atau tingkat keberhasilan tehadap informasi yang ditemukan kembali oleh sistem sebesar 0,961.

4. Sedangkan hasil prediksi dengan menggunakan metode Decision Tree J-48 didapatkan hasil presentasi akurasi untuk data training sebesar $98.9121 \%$, sedangkan hasil untuk akurasi pada data testing sebasar $98.7448 \%$.

5. Dengan keterangan 154 data harga saham yang diklasifikasikan mengalami penaikan harga, dan terdapat 1 data harga saham yang seharusnya mengalami penaikan harga, namun diklasifikasikan mengalami penurunan harga saham. Dan terdapat 82 data harga saham yang diklasifikasikan benar mengalami penurunan harga saham, namun terdapat 2 data harga saham yang seharusnya mengalami penurunan harga saham, tetapi diklasifikasikan mengalami penaikan harga saham.

6. Dengan presentasi untuk nilai precision atau tingkat ketepatan informasi yang diharapkan oleh penulis dengan jawaban yang diberikan oleh sistem. sebesar 0.989 dan nilai untuk recall atau tingkat keberhasilan tehadap informasi yang ditemukan kembali oleh sistem sebesar 0,997.

7. Maka, harga saham yang diprediksi dengan dengan menggunakan program WEKA untuk tanggal 4 Desember 2017 mengalami penaikan harga.

8. Hasil ini juga didukung dengan penaikan harga saham yang ada di website Bursa Efek Indonesia http://ihsg-idx.com/saham/, dengan penaikan harga saham sebesar +125 atau $+1.57 \%$.

\section{Saran}

Adapun saran bagi penelitian ini adalah: 
1. Adanya pembuatan Website sehingga dapat melakukan prediksi harga saham dengan lebih cepat.

2. Menggunakan Metode pengerjaan yang berbeda, seperti penggunaan metode Jaringan Saraf Turuan, K-star, KNN.

3. Penambahan data untuk meningkatkan tinggkat keberhasilannya.

\section{Referensi}

1. Supranto. J, "Pasar Modal Indonesia. Rineka Cipta. Jakarta," Pasar Modal Indones., 1992.

2. D. S. Riswantoro, "Abstrak Penerapan Data Mining Untuk Memprediksikan Fluktuasi Harga Saham Menggunakan Metode Classification Dengan Teknik Dt ( Decision Tree )," pp. 4-5, 2011.

3. M. Ridwan, H. Suyono, and M. Sarosa, "Penerapan Data Mining Untuk Evaluasi Kinerja Akademik Mahasiswa Menggunakan Algoritma Naive Bayes Classifier," Eeccis, vol. 7, no. 1, pp. 59-64, 2013.

I. $\quad$ S. Achmad Basuki, "Decision Tree," p. 2.

4. M. S. H. Hasbullah, H Nasution, "No Title," 2015.

5. S. Fitri, "Perbandingan Kinerja Algoritma Klasifikasi Naïve Bayesian , Lazy-Ibk , Zero-R , Dan Decision Tree- J48," Dasi, vol. 15, no. 1, pp. 33-37, 2014.

6. D. Purnamasari, J. Henharta, Y. P. Sasmita, F. Ihsani, and I. W. S. Wicaksana, "Get Easy Using WEKA," 2013. 